\title{
Gelatinolytic Activity in Tracheal Aspirates of Horses with Chronic Obstructive Pulmonary Disease
}

\author{
By A.-L. Koivunen ${ }^{1}$, P. Maisi ${ }^{1}$, Y. T. Konttinen ${ }^{2}$ and M. Sandholm ${ }^{1}$
}

${ }^{1}$ Department of Clinical Veterinary Sciences, Faculty of Veterinary Medicine, ${ }^{2}$ Institute of Biomedicine, Department of Anatomy, University of Helsinki, and Division of Rheumatic Disease, Fourth Department of Medicine, University Central Hospital, Helsinki, Finland.

\begin{abstract}
Koivunen, A.-L., P. Maisi, Y.T. Konttinen and M. Sandholm: Gelatinolytic activity in tracheal aspirates of horses with chronic obstructive pulmonary disease. Acta vet. scand. 1997, 38, 17-27. - The gelatinolytic activity in tracheal aspirates (TA) of horses with chronic obstructive pulmonary disease (COPD) was analyzed using SDSPAGE-gelatin-gel electrophoresis (zymography) and compared to TAs from healthy controls. The 110-90 kD MMP-9 type gelatinase was high in symptomatic disease phases (permanent disease $0.46 \pm 0.15, \mathrm{p}<0.001$; or intermittent disease $0.47 \pm 0.12$, $\mathrm{p}<0.001)$ compared to healthy controls $(0.10 \pm 0.07)$. Similarly, the overall gelatinolytic activity, the activity in high-mw gelatinolytic bands (210-190 and $150 \mathrm{kD})$ and in proteolytically processed fragments in the $50-40 \mathrm{kD}$ range were high, whereas the $75-65 \mathrm{kD}$ MMP-2 was not altered. These findings suggest that MMP-9 type gelatinases, originating possibly from neutrophils or macrophages, and products thereof have a role in the pathogenesis of equine respiratory diseases, whereas MMP-2 type gelatinases represent house-keeping proteinases involved with normal tissue remodelling. The gelatinolytic activity in TAs correlated with the $\beta$-glucuronidase activity, which indicates that they are simultaneously elevated in the respiratory secretions of horses suffering from COPD and might both be of same origin, or have a causal relationship.
\end{abstract}

protease; proteinase; proteolysis; metalloproteinase; MMP; $\beta$-glucuronidase; equine; lung; tracheal aspirate; COPD.

\section{Introduction}

In northern countries horses are stabled during the long winters and predisposed to dust from hay and bedding. Therefore respiratory diseases due to inhalation irritation are common. Respiratory tract diseases have also been reported to be the second most common cause of poor performance and premature retirement among racehorses (Rossdale et al. 1985) and excess mucus in the trachea has been shown to correlate with poor race performance (MacNamara et al. 1990). Endoscopic examination of racehorses reveals inflammation of the respiratory tract expressed as pharyngeal lymphoid hyperplasia and exudate in the nasopharynx, trachea and bronchial bifurcation in 22\%-50\% of the horses (MacNamara et al. 1990, Burrell 1985, Clarke 1987, Derksen et al. 1991).

Many terms such as chronic obstructive pulmonary disease (COPD), bronchiolitis bronchitis, chronic alveolar emphysema, small airway disease, heaves, allergic bronchiolitis, summer pasture associated COPD, winter barn syndrome, broken wind, hay sickness and chronic airway disease (Derksen et al. 1991) and most recently inflammatory airway disease (IAD) (Moore 1995) have been used to describe 
equine respiratory diseases. Increased numbers of neutrophils are detected in the tracheal fluid samples in horses with COPD (Beech 1991). Pulmonary function tests have been used to assess the severity of COPD and to document the presence of airway obstruction (Derksen 1991). In the present paper COPD is used to describe the syndrome ranging from mild chronic recurrent cough and exudate in trachea and bronchial bifurcation to expiratory dyspnea and chronic purulent nasal discharge in the chronic respiratory cripple (Derksen 1991).

Horses with COPD have been shown to have proteolytic activity in their respiratory tract secretions (Grünig 1985, Koivunen et al. 1996). Some of this proteolytic activity has been shown to be of plasmin origin (Sandholm et al. 1990), whereas free (uninhibited) elastase, as in humans, has not been found in tracheal aspirates of horses with COPD (Grünig 1985). The specific and potent serine protease inhibitors DFP and PMSF did not abolish the proteolytic activity of tracheal aspirates in vitro, suggesting that serine proteases may not play any major role in the pathogenesis of COPD (Koivunen et al. 1996). In addition to serine proteinases, matrix metalloproteinases (MMPs) are thought to play an important role in the degradation of the extracellular matrix of the lung tissue and thus in the pathogenesis of various respiratory diseases in man (Stockley 1983, Campbell et al. 1987, Sibille \& Reynolds 1990). The MMP family includes a $72 \mathrm{kD}$ gelatinase MMP-2 (also known as $72 \mathrm{kD}$ type IV collagenase or gelatinase A) and a $92 \mathrm{kD}$ gelatinase MMP-9 (also known as $92 \mathrm{kD}$ type IV collagenase or gelatinase B (Campbell et al. 1987, Hibbs et al. 1987, Woessner 1991)). These gelatinases have an almost identical substrate specificity profile and degrade denatured collagen (gelatin), type IV collagen, native type V, VII and X collagens, and elastin (Weiss 1989, Senior et al. 1991). MMP-2 has also some ability to degrade prote- oglycans and fibronectin (Collier et al. 1988). MMP-2 is produced by fibroblasts (Hibbs et al. 1991), macrophages (Garbisa et al. 1986), endothelial cells (Kalebic et al. 1983) as well as by malignant cells (Kusukawa et al. 1992). Neutrophils are a major source of MMP-9. Minor sources include macrophages and epithelial cells (Hibbs et al. 1987, Weiss 1989, Mainardi et al. 1991, Campbell et al. 1991).

To clarify the eventual presence, type and extent of gelatinolytic MMPs in the respiratory tract secretions of horses with COPD, tracheal aspirates (TA) were assessed using solid phase gelatin substrate gel in zymography, analyzed with densitometry. A lysosomal enzyme, $\beta$-glucuronidase, shown to be an indicator of seasonal airway irritation in the respiratory tract secretions of horses (Maisi et al. 1994) was assessed parallelly. Horses with signs of permanent or intermittent COPD were compared to healthy controls.

\section{Materials and methods}

\section{Horses}

Tracheal aspirates $(\mathrm{n}=30)$ were collected from 3 categories: Horses (age $11.8 \pm 4.3$ ) with a healthy respiratory tract (10 samples), horses (age $10.4 \pm 3.8$ ) with intermittent signs of COPD in symptomatic disease stage (10 samples) and horses (age $12.4 \pm 3.1$ ) with permanent signs of COPD (10 samples).

Healthy horses had no history or signs of a respiratory disease based on the clinical examination of the respiratory tract, endoscopic examination of the respiratory tract, analysis of the neutrophil content of the tracheal mucus, measurement of the intrapleural pressure difference (Deegen \& Klein 1987), and arterial-alveolar (AA) oxygen difference (Deegen 1987). Diseased horses had a history of a chronic intermittent or permanent respiratory disease, purulent 
mucus detectable in the trachea and in the bronchial bifurcation by endoscopy, and the neutrophil content of the tracheal mucus was elevated. The total leucocyte count, the concentration of fibrinogen and haemoglobin in blood as well as the body temperature were within the normal limits in all the healthy and diseased horses. The horses had not been under medication for at least one month before sampling of the tracheal mucus.

\section{Sampling of the tracheal mucus}

A tracheal wash was performed with a sterile catheter inserted through the biopsy channel of an endoscope (Olympus CF, Olympus Optical Company, Tokyo, Japan; type IB, length 140 $\mathrm{cm}$ ). Ten $\mathrm{ml}$ of $0.9 \%$ saline was infused into mid-trachea and the aspiration sample was sucked without delay from the pool formed in the lower tracheal floor. The tracheal aspirates (TA) were stored at $-20^{\circ} \mathrm{C}$ for further studies.

\section{Correction for the dilution effect of the tracheal aspirate}

To analyze the dilution effect due to tracheal wash, the urea concentration was analyzed in parallel from the blood serum and the tracheal wash using the method of Guttmann \& Bergmeyer (1974). The dilution effect was calculated according to Rennard et al. (1986).

\section{$\beta$-glucuronidase}

$\beta$-glucuronidase (EC 3.2.1.31) was determined by a fluorescence method using the fluorogenic substrate 4-methyl-umbelliferyl- $\beta$-glucuronide on a microtitration plate (Maisi et al. 1994) a modification of the method used by Kolodny \& Mumford (1976). The fluorometric assays were carried out by using the Fluoroscan II fluorometer (Labsystems, Pulttitie 8, Helsinki, Finland). The activity is expressed as nmol product (4-methylumbelliferone) released $/ \mathrm{ml} / \mathrm{min}$ at $25^{\circ} \mathrm{C}$.
Preparation of the samples for zymography

Before the assay the TA samples were centrifuged for $4 \mathrm{~min}$ at $170 \mathrm{G}$ (Biofuge A, Heraeus, Sepatech, Germany). The dilution coefficient (based on blood-tracheal aspirate urea gradient) was used to dilute each TA sample to the same dilution for zymography using TNC-buffer (0.05 M Tris-HCl, $0.005 \mathrm{M} \mathrm{CaCl}_{2}, 0.2 \mathrm{M}$ $\mathrm{NaCl}_{2}, \mathrm{pH} 7.5$ ).

\section{Zymography}

Zymography was performed as described in detail elsewhere (Sepper et al. 1994). The TA samples and the control samples were diluted 2:1 with the sample buffer and pre-incubated for $2 \mathrm{~h}$ at $20^{\circ} \mathrm{C}$. The sample buffer, $\mathrm{pH} 6.8$, contained 0.118 M Tris (Sigma T-1378), $0.064 \mathrm{M}$ $\mathrm{H}_{3} \mathrm{PO}_{4}$ (Merck Art 573), with 20\% glycerol, $0.04 \%$ bromphenol blue (Merck Art 8122) and $6 \%$ sodium dodecyl sulfate (SDS)(BDH prod. 44244). Samples were then loaded into $11 \%$ SDS-PAGE gels containing $1 \mathrm{mg} / \mathrm{ml}$ porcine skin gelatin (Sigma G-2625) as the substrate. One lane was loaded with Prestained SDSPAGE high range molecular weight standard (Bio-Rad, Richmond, CA, USA). Human peripheral blood neutrophil gelatinase, human skin fibroblast gelatinase, prepared as described by Konttinen et al. (1991), and TNC buffer were used as controls (Fig. 1).

Analysis of the gelatinolytic activity on the SDS-PA-gelatin-gels

The gelatinolytic activity was visualized as clear bands against the blue background (Fig. 1). For scanning of the gelatinolytic bands the gels were placed on an even-light translumination table, recorded using a CCTV videocamera provided with zoom kino-lens system and linked to a semi-automatic Kontron image analysis and processing systems (Kontron Bildanalyse GMBH, Eching, Germany) equipped with a VIDAS 2.1 programme (Kontron Elektronik 


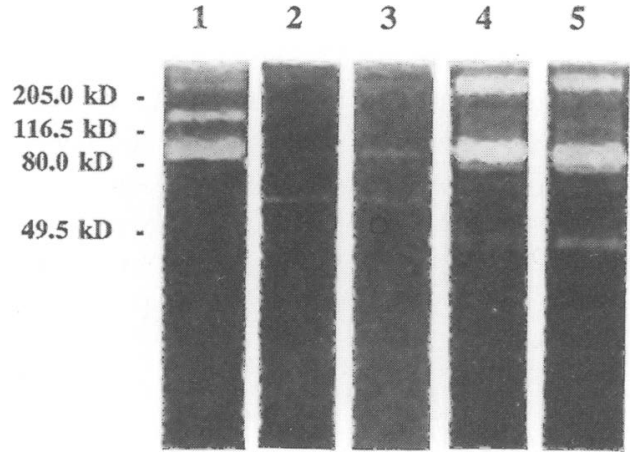

Figure 1. Gelatin zymographies of positive controls and of one example from each category of horses. Lane 1: human PMN extract (MMP-9 control), Lane 2: human fibroblast supernatant (MMP-2 control), Lane 3: tracheal aspirate (TA) from a healthy horse, Lane 4: TA from an intermittently diseased horse in its symptomatic stage, Lane 5: TA from a horse with permanent COPD.

GMBH, Eching, Germany). A frame grabber installed in the computer converted the analog video signal to a $512 \times 512$ pixel array. Results were expressed in numbers of the mean grey level (range from 0 to 255 pixels; 255 for white and 0 for black). The background grey level of the gel was substracted from the mean grey values of the electrophoretic bands and the densitometric results were calculated in area mode (Fig. 2).

The gelatinolytic activity of each sample was compared to the activity of the neutrophil gelatinase standard run in the same electrophoretic run. The gelatinolytic activities of different bands were expressed in relation to the corresponding neutrophil standard.

For interpolation of molecular weights of the proteinases in different bands, a standard curve was prepared using a least square log-linear computer fitting $(\mathrm{X}=$ distance migrated by standard (mm), Y $=\log$ of the molecular weight of that standard).

\section{Statistical analysis}

The Mann-Whitney test (Statgraphics ${ }^{\circledR}$, Manugistics, Rockville, MO, USA) was used to test the differences in gelatinolytic activity between healthy, intermittently symptomatic and permanently symptomatic horses (Table 1). The Spearman rank correlation coefficient was used to test the interdependences between the gelatinolytic activity, the activity of $\beta$-glucuronidase and the number of neutrophils in the tracheal fluid. Differences were regarded as significant at the 0.05 probability level.

\section{Results}

All horses showed detectable gelatinolytic activity in their tracheal aspirates. In addition to prominent neutrophil type $92 \mathrm{kD}$ (MMP-9) and faint fibroblast type $72 \mathrm{kD}$ gelatinases (MMP2), high molecular weight forms (210-190 kD and $150 \mathrm{kD}$ ) and low molecular weight forms in the $50-40 \mathrm{kD}$ range were observed (Fig. 1, Table 1).

TAs from horses with COPD showed significantly higher overall gelatinolytic activity $(p<0.001)$ and higher gelatinolytic activities in the mw ranges of $210-190 \mathrm{kD}(\mathrm{p}<0.001), 150$ $\mathrm{kD}(\mathrm{p}<0.001)$ and $110-90 \mathrm{kD}(\mathrm{p}<0.001)$ compared to healthy controls (Table 1). Gelatinase with the molecular weight of $110-90 \mathrm{kD}$ comigrated within the same molecular weight region as the gelatinase of the human neutrophil standard (MMP-9)(Fig. 1).

Most of the samples (9/10 healthy, 18/20 diseased) contained traces of gelatinase activity moving in the $75-65 \mathrm{kD}$ range, corresponding to MMP-2 in the fibroblast standard. There was no apparent difference in the activity of this gelatinase between the healthy and the symptomatic horses.

Low molecular weight gelatinolytic activity in the range of $50-40 \mathrm{kD}$ was detected in all symptomatic horses and in most $(9 / 10)$ of the healthy 

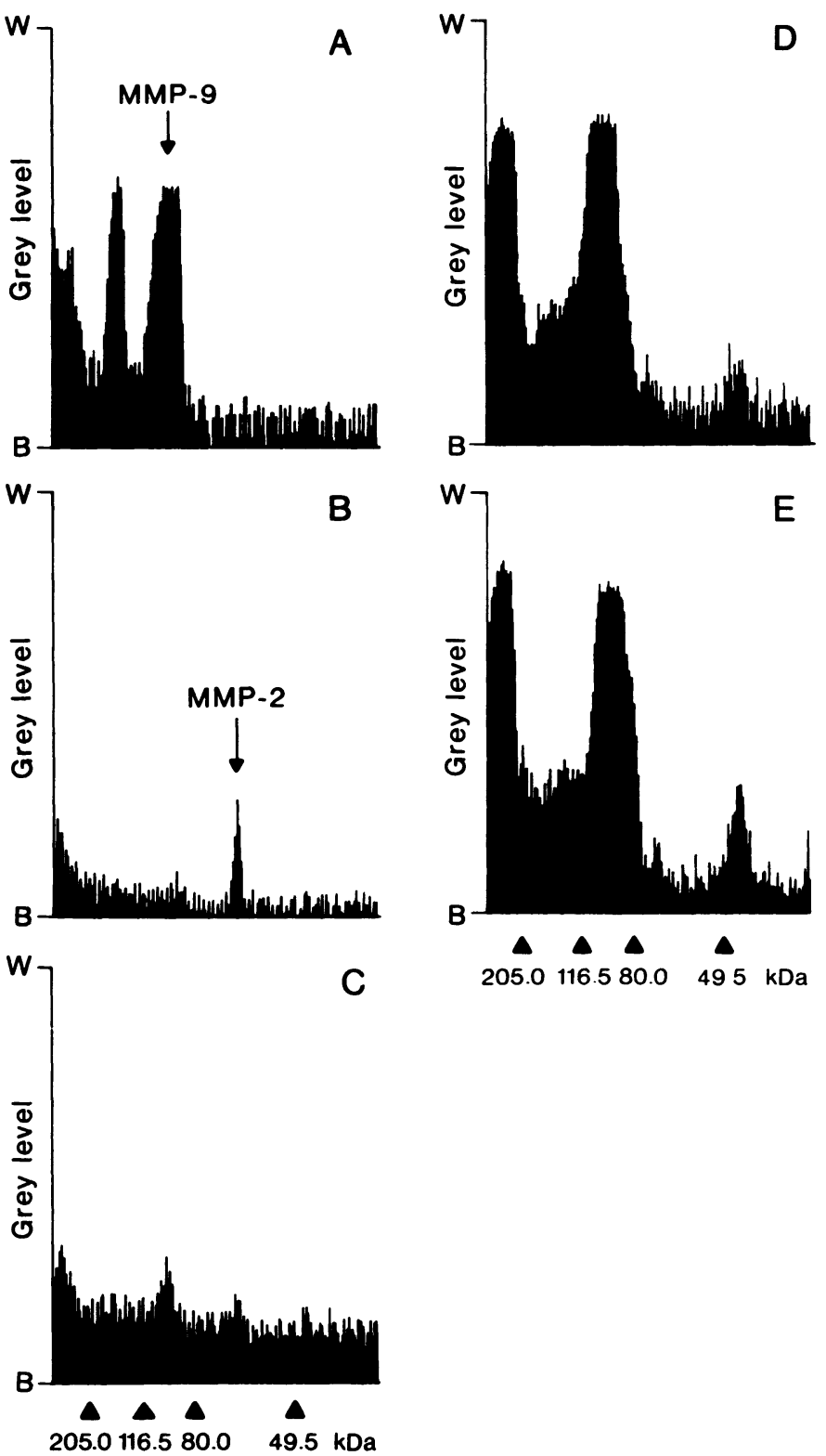

Figure 2. Densitometric curves from the samples depicted in Fig. 1 generated with an image analyzer (VIDAS 2.1). A: human PMN extract (MMP-9 control), B: human fibroblast supernatant (MMP-2 control), C: tracheal aspirate (TA) from a healthy horse, D: TA from an intermittently diseased horse in its symptomatic stage, E: TA from a horse with permanent COPD. The area under the curve corresponds to the gelatinolytic activity of the tracheal aspirate. The molecular weight standards are indicated on $\mathrm{X}$-axis. $\mathrm{B}=$ black, corresponding to 0 pixels and $\mathrm{W}=$ white, corresponding to 255 pixels. 
Table 1. The overall gelatinolytic activity, the activities of separate gelatinolytic bands (average \pm SD median, lower quartile - upper quartile) as related to the neutrophil standard, and activity of $\beta$-glucuronidase $\left(\mathrm{nmol} / \mathrm{ml} / \mathrm{min}\right.$ at $\left.25^{\circ} \mathrm{C}\right)$ of tracheal aspirates in healthy controls, in intermittently diseased (symptomatic stage) and permanently diseased horses (COPD).

\begin{tabular}{|c|c|c|c|}
\hline & $\begin{array}{l}\text { Healthy } \\
\text { controls } \\
(\mathrm{n}=10)\end{array}$ & $\begin{array}{l}\text { Intermittent disease, } \\
\text { symptomatic } \\
\text { stage }(\mathrm{n}=10)\end{array}$ & $\begin{array}{l}\text { Permanent } \\
\text { disease } \\
(\mathrm{n}=10)\end{array}$ \\
\hline & & $* * *$ & $* * *$ \\
\hline \multirow[t]{2}{*}{ Overall } & $\begin{array}{l}0.27 \pm 0.13 \\
0.20(0.18-0.37)\end{array}$ & $\begin{array}{l}1.19 \pm 0.39 \\
1.14(0.92-1.62)\end{array}$ & $\begin{array}{l}1.24 \pm 0.78 \\
0.94(0.70-1.43)\end{array}$ \\
\hline & & $* * *$ & $* * *$ \\
\hline \multirow[t]{2}{*}{$210-190 \mathrm{kD}$} & $\begin{array}{l}0.08 \pm 0.04 \\
0.08(0.04-0.09)\end{array}$ & $\begin{array}{l}0.28 \pm 0.12 \\
0.29(0.19-0.36)\end{array}$ & $\begin{array}{l}0.30 \pm 0.13 \\
0.27(0.21-0.39)\end{array}$ \\
\hline & & $* * *$ & $* * *$ \\
\hline \multirow[t]{2}{*}{$150 \mathrm{kD}$} & $\begin{array}{l}0.02 \pm 0.01 \\
0.02(0.02-0.03)\end{array}$ & $\begin{array}{l}0.11 \pm 0.07 \\
0.09(0.06-0.15)\end{array}$ & $\begin{array}{l}0.09 \pm 0.08 \\
0.05(0.04-0.11)\end{array}$ \\
\hline & & $* * *$ & $* * *$ \\
\hline $110-90 \mathrm{kD}$ & $\begin{array}{l}0.10 \pm 0.07 \\
0.07(0.05-0.14)\end{array}$ & $\begin{array}{l}0.47 \pm 0.12 \\
0.46(0.41-0.58)\end{array}$ & $\begin{array}{l}0.46 \pm 0.15 \\
0.43(0.36-0.61)\end{array}$ \\
\hline $75-65 \mathrm{kD}$ & $\begin{array}{l}0.01 \pm 0.01 \\
0.01(0.00-0.01)\end{array}$ & $\begin{array}{l}0.01 \pm 0.01 \\
0.02(0.01-0.02)\end{array}$ & $\begin{array}{l}0.02 \pm 0.03 \\
0.01(0.00-0.02)\end{array}$ \\
\hline $50-40 \mathrm{kD}$ & $\begin{array}{l}0.02 \pm 0.03 \\
0.01(0.00-0.02)\end{array}$ & $\begin{array}{l}* * \\
0.07 \pm 0.05 \\
0.05(0.04-0.08)\end{array}$ & $\begin{array}{l}* \\
0.09 \pm 0.12 \\
0.04(0.03-0.11)\end{array}$ \\
\hline & & $*$ & \\
\hline $\begin{array}{l}\beta \text {-glucur- } \\
\text { onidase }\end{array}$ & $\begin{array}{l}39.3 \pm 39.2 \\
30.5(1.5-67.6)\end{array}$ & $\begin{array}{l}108.2 \pm 60.1 \\
105.1(63.2-134.3)\end{array}$ & $\begin{array}{l}61.0 \pm 43.0 \\
54.0(28.4-84.4)\end{array}$ \\
\hline
\end{tabular}

$*=\mathrm{p}<0.05,{ }^{* *}=\mathrm{p}<0.01,{ }^{* * *}=\mathrm{p}<0.001$, compared to activities of the healthy controls.

$\mathrm{n}=$ number of samples.

horses (Table 1). This activity was significantly higher in the TAs of the symptomatic horses $(p<0.05$ for permanently diseased, $p<0.01$ for intermittently diseased; Table 1) than in the healthy controls.

No significant difference was evident between the gelatinolytic activities of TAs from horses suffering from intermittent or permanent disease. $\beta$-glucuronidase in TAs from intermittently diseased horses at their symptomatic stage was significantly higher as compared to healthy horses $(\mathrm{p}<0.05$, Table 1$)$.

The overall gelatinolytic activity showed a highly significant correlation $(\mathrm{p}<0.001)$ with the activity of $\beta$-glucuronidase and significant correlation $(\mathrm{p}<0.01)$ with the number of neutrophils. The $110-90 \mathrm{kD}$ area (MMP-9) showed 
Table 2. Correlation between gelatinase activities, activity of $\beta$-glucuronidase and number of neutrophils in tracheal fluid of healthy horses and of horses suffering from COPD. The upper number indicates the correlation coefficient and the lower number the significance level (p) each time.

\begin{tabular}{|c|c|c|c|c|c|c|c|c|}
\hline & Overall & $\begin{array}{l}210-190 \\
\mathrm{kD}\end{array}$ & $\begin{array}{l}150 \\
\mathrm{kD}\end{array}$ & $\begin{array}{l}110-90 \\
\mathrm{kD}\end{array}$ & $\begin{array}{c}75-65 \\
\mathrm{kD}\end{array}$ & $\begin{array}{c}50-40 \\
\mathrm{kD}\end{array}$ & $\begin{array}{l}\text { B-glucu- } \\
\text { roni- } \\
\text { dase }\end{array}$ & $\begin{array}{c}\text { Number of } \\
\text { neutro- } \\
\text { phils }\end{array}$ \\
\hline Overall & $\begin{array}{l}1.00 \\
0.000\end{array}$ & & & & & & & \\
\hline $210-190 \mathrm{kD}$ & $\begin{array}{l}0.91 \\
0.000\end{array}$ & $\begin{array}{l}1.00 \\
0.000\end{array}$ & & & & & & \\
\hline $150 \mathrm{kD}$ & $\begin{array}{l}0.92 \\
0.000\end{array}$ & $\begin{array}{l}0.78 \\
0.000\end{array}$ & $\begin{array}{l}1.00 \\
0.000\end{array}$ & & & & & \\
\hline $110-90 \mathrm{kD}$ & $\begin{array}{l}0.98 \\
0.000\end{array}$ & $\begin{array}{l}0.91 \\
0.000\end{array}$ & $\begin{array}{l}0.89 \\
0.000\end{array}$ & $\begin{array}{l}1.00 \\
0.000\end{array}$ & & & & \\
\hline $75-65 \mathrm{kD}$ & $\begin{array}{l}0.46 \\
0.014\end{array}$ & $\begin{array}{l}0.25 \\
0.181\end{array}$ & $\begin{array}{l}0.50 \\
0.009\end{array}$ & $\begin{array}{l}0.51 \\
0.007\end{array}$ & $\begin{array}{l}1.00 \\
0.000\end{array}$ & & & \\
\hline $50-40 \mathrm{kD}$ & $\begin{array}{l}0.80 \\
0.000\end{array}$ & $\begin{array}{l}0.66 \\
0.001\end{array}$ & $\begin{array}{l}0.66 \\
0.001\end{array}$ & $\begin{array}{l}0.75 \\
0.000\end{array}$ & $\begin{array}{l}0.30 \\
0.116\end{array}$ & $\begin{array}{l}1.00 \\
0.000\end{array}$ & & \\
\hline$\beta$-glucuronidase & $\begin{array}{l}0.61 \\
0.001\end{array}$ & $\begin{array}{l}0.47 \\
0.012\end{array}$ & $\begin{array}{l}0.60 \\
0.002\end{array}$ & $\begin{array}{l}0.59 \\
0.002\end{array}$ & $\begin{array}{l}0.37 \\
0.051\end{array}$ & $\begin{array}{l}0.63 \\
0.001\end{array}$ & $\begin{array}{l}1.00 \\
0.000\end{array}$ & \\
\hline $\begin{array}{l}\text { Number of neutro- } \\
\text { phils }\end{array}$ & $\begin{array}{l}0.49 \\
0.010\end{array}$ & $\begin{array}{l}0.52 \\
0.006\end{array}$ & $\begin{array}{l}0.51 \\
0.007\end{array}$ & $\begin{array}{l}0.48 \\
0.012\end{array}$ & $\begin{array}{l}0.02 \\
0.919\end{array}$ & $\begin{array}{l}0.27 \\
0.148\end{array}$ & $\begin{array}{l}0.37 \\
0.050\end{array}$ & $\begin{array}{l}1.00 \\
0.000\end{array}$ \\
\hline
\end{tabular}

Numbers in boldface type indicate statistically significant results $(\mathrm{p}<0.05)$.

significant correlation both to the activity of $\beta$-glucuronidase $(\mathrm{p}<0.01)$ and the number of neutrophils $(\mathrm{p}<0.05)$. Interestingly the $50-40$ $\mathrm{kD}$ area showed highly significant correlation to the activity of $\beta$-glucuronidase, but did not correlate with the number of neutrophils.

\section{Discussion}

In the present study significantly higher gelatinolytic activity was detected in TAs from horses with COPD compared to healthy horses (Table 1). These findings resemble those reported on acute and chronic lung diseases in man (Campbell et al. 1987) and suggest that metalloprotei- nases are important in the pathogenesis of equine respiratory diseases, at least as markers of actively ongoing disease and probably also as significant mediators of local tissue destruction.

Gelatinases, members of the matrix metalloproteinase family (MMPs) of neutral endoproteinases, participate in various inflammatory processes in the human lung (Sibille \& Reynolds 1990, Campbell et al. 1987). MMPs are secreted in an inactive form, and oxidation appears to be an important activation mechanism of metalloproteinases in vivo (Weiss et al. 1989, Saari et al. 1990). Neutrophil (PMN) degranu- 
lation is almost always accompanied by the generation of reactive oxygen species (Mainardi et al. 1991). Therefore, PMNs are thought to regulate local proteolytic processes by releasing proteinases (such as proMMP-9) and by inducing their oxidative and/or proteolytic activation (Woessner 1991, Desvrivieres 1993).

The appearance of proteolytic activity is ultimately dependent on the proteinase/proteinase inhibitor balance. $\alpha 2$-macroglobulin and TIMPs (tissue inhibitors of metalloproteinases) are powerful downregulators of other metalloproteinases, but appear to be less effective against the neutrophil derived enzymes (Weiss 1989). In inflammation, these inhibitors may become inactivated by oxidative or by proteolytic processes leading to an imbalance between metalloproteinases and their inhibitors, which allows unregulated metalloproteinases to attack lung tissue (Weiss 1989).

Total proteinase activity in TAs, as measured by the hide powder azure as a substrate, has been shown to correlate with the number of neutrophils in horses with COPD (Grünig et al. 1985). This correlation can be explained by neutrophils playing an important role, not only in secretion, but also in activation of metalloproteinases and other proteolytic enzymes.

Neutrophils are a major source of MMP-9 (110-90 kD range), minor sources include macrophages and epithelial cells (Hibbs et al. 1987, Weiss 1989, Mainardi et al. 1991, Campbell et al. 1991).

In the present study free MMP-9 type gelatinase was detected in excess in the TA of horses suffering from symptoms of an intermittent or permanent COPD (Table 1). Additionally, increases in the high molecular weight (210-190 $\mathrm{kD}, 150 \mathrm{kD}$ ) gelatinolytic bands were observed in the symptomatic horses, which might represent enzyme aggregates or enzyme-regulatory protein complexes.

Gelatinases of the TAs in the range of $110-90$
$\mathrm{kD}$ (MMP-9) migrated slightly faster than the human neutrophil standard. There is a species dependent molecular weight variation among different groups of gelatinases. Pigs have $97 \mathrm{kD}$ neutrophil gelatinase, which is structurally highly related to the human $92 \mathrm{kD}$ gelatinase (Senior et al. 1991). On the other hand, human neutrophil gelatinase migrates on SDS gels slightly slower than the macrophage enzyme (Mainardi et al. 1991). The faster migration in the $110-90 \mathrm{kD}$ range could be explained by the differences between human and horse gelatinases, or by the macrophage origin of the TA gelatinases in the present study.

When the various molecular forms of gelatinolytic activities were compared between healthy and diseased horses, significant differences were observed in all activities except for that in the $75-65 \mathrm{kD}$ range corresponding the fibroblast supernatant standard. Apparently this gelatinase is not of major importance in the pathogenesis of equine COPD but rather represents a house-keeping enzyme involved in the normal tissue remodelling processes.

The small molecular weight activities seen in the range of $50-40 \mathrm{kD}$ might represent split products of proteolytic enzymes (Hibbs et al. 1987, Mainardi et al. 1991).

Peribronchial fibrosis has been shown to occur in well advanced equine COPD (Van den Ingh 1985). Proteases from equine polymorphonuclear leucocytes degrade fibrinogen (Koj et al. 1976). This might decrease fibrin deposition. On the other hand, the proteolytic activity in the respiratory secretion takes part in destructive inflammatory processes in the lung tissue. If the destructive role of various proteases is important in the pathogenesis of equine COPD, one should search for pharmacologically active inhibitors for each proteinase. Some synthetic inhibitors have shown promise in inactivating human metalloproteinases in vitro (Woessner 1991) and in vivo (Lauhio et al. 1994a,b). 


\section{Acknowledgement}

This study was supported by the University of Veterinary Medicine, Emil Aaltonen foundation, the Academy of Finland and Astra Research Foundation.

\section{References}

Beech J: Tracheobronchial aspirates. In: Beech J (ed.): Equine respiratory disorders. Lea and Febiger, Philadelphia, USA. 1991, pp 41-53.

Burrell $M H$ : Endoscopic and virological observations on respiratory disease in a group of young Thoroughbred horses in training. Equine vet. J. 1985, 17, 99-103.

Campbell EJ, Cury JD, Shapiro SD, Goldberg GI, Welgus $H G$ : Neutral proteinases of human mononuclear phagocytes. Cellular differentiation markedly alters cell phenotype for serine proteinases, metalloproteinases, and tissue inhibitor of metalloproteinases. J. Immunol. 1991, 146, 1286-1293.

Campbell EJ, Senior RM, Welgus HG: Extracellularmatrix injury during lung inflammation. Chest 1987, 92, 161-167.

Clarke $A F$ : Chronic pulmonary disease - A multifaceted disease complex in the horse. Ir. vet. J. 1987 , 41, 258-264.

Collier IE, Wilhelm SM, Eisen AZ, Marmer BL, GRANT GA, Selzer JL, Kronberger AHC, Bauer $E A$, Goldberg GI: H-ras oncogene-transformed human bronchial epithelial cells (TBE-1) secrete a single metalloprotease capable of degrading basement membrane collagen. J. Biol. Chem. 1988, 263, 6579-6587.

Deegen E: Das chronisch lungenkranke Pferd und sein Einsatz im Sport. (Horse with a chronic lung disease and its input in sport.). Praktische Tierartz 1987, 68, 15-19.

Deegen $E$, Klein H-K: Interpleural pressure measurement and bronchial spasmolysis tests in the horse performed with transportable oesophageal pressure measuring instrument. Pferdeheilkunde 1987, 3, 213-221.

Derksen FJ: Chronic obstructive pulmonary disease. In: Beech, J. (ed.): Equine respiratory disorders, Lea \& Febiger, Philadelphia, USA, 1991, 223235.

Derksen F, Arthur RM, Dillon G, Pascoe J, Sweeney $C$ : A round table discussion on chronic obstructive pulmonary disease (COPD). Equine Practice 1991, 13, 25-28.

Desrivieres $S$, Lu H, Peyri N, Soria C, Legrand Y, Me- nashi S: Activation of the $92 \mathrm{kDa}$ type IV collagenase by tissue kallikrein. J. Cell. Physiol. 1993, 157, 587-593.

Garbisa S, Ballin M, Daga-Gordini D, Fastelli G, Naturale $M$, Negro A, Semenzato G, Liotta LA: Transient expression of type IV collagenolytic metalloproteinase by human mononuclear phagocytes. J. Biol. Chem. 1986, 261, 2369-2375.

Grünig $G$ : Proteaseaktivität im Tracheobronchialsekret von Pferden mit COPD: Pathophysiologische Bedeutung. (Protease activity in tracheobronchial secretions of horses with COPD and its relevance for pathogenesis.). Pferdeheilkunde 1985, 1, 55-63.

Guttmann I, Bergmeyer HU: Determination of urea with glutamate dehydrogenase as indicator enzyme. In: Bergmayer, HU (ed.): Methods of enzymatic analysis. 2nd ed. Academic Press, New York. 1974, pp. 1794-1798.

Hibbs DS, Hembry RM, Docherty APJ, Reynolds JJ: Purification and characterization of human 72$\mathrm{kDa}$ gelatinase (type IV collagenase). Use of immunolocalization to demonstrate the noncoordinate regulation of the $72-\mathrm{kDa}$ and $95-\mathrm{kDa}$ gelatinases by human fibroblasts. Biol. Chem. Hoppe-Seyler 1991, 372, 287-296.

Hibbs MS, Hoidal JR, Kang AH: Expression of a metalloproteinase that degrades native type $\mathrm{V}$ collagen and denatured collagens by cultured human alveolar macrophages. J. Clin. Invest. 1987, 80, 1644-1650.

Kalebic T, Garbisa S, Glaser B, Liotta LA: Basement membrane collagen: Degradation by migrating endothelial cells. Science 1983, 221, 281-283.

Koivunen A-L, Maisi P, Fang W, Sandholm M: Inhibition of the protease activity in tracheobronchial aspirates of horses with COPD. Amer. J. vet. Res. 1996, 57, 603-607.

Koj A, Chudnik J, Dubin A: Substrate specificity and modification of the active center of elastase-like neutral proteinases from horse blood leucocytes. Biochem. J. 1976, 153, 397-402.

Kolodny EH, Mumford RA: Human leucocyte acid hydrolases: Characterization of eleven lysosomal enzymes and study of reaction conditions for their automated analysis. Clin. Chim. Acta 1976, 70, 247-257.

Konttinen YT, Lindy $O$, Suomalainen $K$, Ritchlin $C$, Saari H, Vauhkonen $M$, Lauhio A, Santavirta $S$, Sorsa $T$ : Substrate specificity and activation mechanisms of collagenase from human rheumatoid synovium. Matrix 1991, 11, 395-403. 
Kusukawa J, Sasaguri Y, Shima I, Kameyama T, Morimatsu $M$ : Production of matrix metalloproteinase 2 (gelatinase/ type IV collagenase) and 3 (stromelysin) by cultured oral squamous cell carcinoma. J. Oral Pathol. 1992, 21, 221-224.

Lauhio A, Konttinen YT, Tschesche H, Nordström D, Salo T, Lähdevirta J, Golub LM, Sorsa T: Reduction of matrix metalloproteinase-8 levels during long-term doxycycline treatment. Antimicrob. Agents and Chemother. 1994a, 38, 400-402.

Lauhio A, Salo T, Ding Y, Konttinen YT, Nordström D, Tschesche H, Lähdevirta J, Golub LM, Sorsa T: In vivo inhibition of human neutrophil collagenase (MMP-8) activity during long-term combination therapy of doxycycline and NSAID in acute reactive arthritis. Clin. Exp. Immunol. 1994b, 98, 21-28.

MacNamara B, Bauer S, Iafe J: Endoscopic evaluation of exercise-induced pulmonary haemorrhage and chronic obstructive pulmonary disease in association with poor performance in racing Standardbreds. J. Amer. vet. med. Assoc. 1990, 196, 443-445.

Mainardi CL, Pourmotable TF, Hasty KA: Inflammatory phagocytes and connective tissue degrading metalloproteinases. Amer. J. med. Sci. 1991, 302, 171-175.

Maisi P, Koivunen A-L, Rantala A-R, Turgut $K$ : $\beta$ glucuronidase and trypsin inhibitor capacity of tracheal lavage fluid as indicators of seasonal airway irritation in the horse. Equine vet. J. 1994, 26, 385-391.

Moore BR, Krakowka S, Robertson JT, Cummings $J M$ : Cytologic evaluation of bronchoalveolar lavage fluid obtained from Standardbred racehorses with inflammatory airway disease. Amer. J. vet. Res. 1995, 56, 562-567.

Rennard S, Basset $G$, Lecossier D, ODonnel K, Martin P, Crystal RG: Estimation of volume of epithelial lining fluid recovered by lavage by using urea as a marker of dilution. J. Appl. Physiol. 1986, 60, 532-538.

Rossdale PD, Hopes R, Wingfield Digby NJ, Offord $K$ : Epidemiological study of wastage among racehorses 1982 and 1983. Vet. Rec. 1985, 116, 66-69.

Saari H, Suomalainen $K$, Lindy $O$, Konttinen $Y T$, Sorsa T: Activation of latent human neutrophil collagenase by reactive oxygen species and serine proteases. Biochem. Biophys. Res. Commun. 1990, 171, 979-987.

Sandholm M, Järvinen M, Halonen S, Eriksson A,
Nyholm K, Maisi P: Enzymology of tracheal lavage fluid in horses with bronchial hyperreactivity. In: Proceedings of the International Society for Animal Clinical Biochemistry. Ed: J.J. Kaneko, Davis, California, USA. 1990, pp. 51-157.

Senior RM, Griffin GL, Fliszar CJ, Shapiro SD, Goldberg GI, Welgus HG: Human 92- and 72-kilodalton type IV collagenases are elastases. J. Biol. Chem. 1991, 266, 7870-7875.

Sepper R, Konttinen YT, Sorsa T, Koski H: Gelatinolytic and type IV collagenolytic activity in bronchiectasis disease. Chest 1994, 106, 1129-1133.

Sibille Y, Reynolds HY: Macrophages and polymorphonuclear neutrophils in lung defense and injury. Am. Rev. Respir. Dis. 1990, 141, 471-501.

Stockley $R A$ : Proteolytic enzymes, their inhibitors and lung diseases. Clinical Science 1983, 64, 119-126.

Van den Ingh TSGAM: Morphological aspects of bronchitis and bronchiolitis in the horse. In: Deegen E, Beadle RE. Hippiatrika (eds.): Proceedings of the international symposium of lung function and respiratory diseases in the horse. Germany. 1985, pp. 13-15.

Weiss SJ: Tissue destruction by neutrophils. New Engl. J. Med. 1989, 320, 365-376.

Woessner JF: Matrix metalloproteinases and their inhibitors in connective tissue remodelling. FASEB J. 1991, 5, 2145-2154.

\section{Sammanfattning}

Gelatinolytisk aktivitet $i$ trakealaspirat från hästar med kronisk obstruktiv lungsjukdom.

Den gelatinolytiska aktiviteten i trakealaspirat (TA) från hästar med kronisk obstruktiv lungsjukdom (COPD) undersöktes med SDS-PAGE-gelatin-gelelektrofores (zymografi) och jämfördes med TA från friska kontrollhästar. Gelatinasaktiviteten av typ MMP-9 på 110-90 kD var hög i TA från hästar under symptomgivande faser av sjukdomen $(0.46 \pm 0.15$, $\mathrm{p}<0,001$ i TA från hästar med ihållande sjukdom; $0.47 \pm 0.12, \mathrm{p}<0,001$ med intermittent sjukdom) $\mathrm{i}$ jämförelse med friska djur $(0.10 \pm 0.07)$. Också den totala gelatinolytiska aktiviteten, aktiviteten i gelatinaser med hög molekylvikt (210 - 190 samt $150 \mathrm{kD})$ samt aktiviteten i fragment på 50 - $40 \mathrm{kD}$ som genomgått proteolys var höga, medan aktiviteten $\mathrm{i}$ MMP-2 på 75 - $65 \mathrm{kD}$ var opåverkad. Dessa fynd antyder att gelatinaser av typ MMP-9, som eventuellt 
härstammar från neutrofiler eller makrofager, samt nedbrytningsprodukter av gelatinas av denna typ spelar en roll i patogenesen av respiratoriska sjukdomar hos hästar, medan gelatinaser av typ MMP-2 utgör en grupp proteinaser som behövs för den normala ämnesomsättningen och återuppbyggnaden av väv- nader. Den gelatinolytiska aktiviteten i TA korrelerade med $\beta$-glukuronidasaktiviteten, vilket tyder på att aktiviteten hos dessa båda enzymer är stegrad i luftvägssekret hos hästar med COPD. Dessa enzymer kan tänkas ha gemensamt ursprung eller deras aktivitet står måhända i kausalsamband med varandra.

(Received April 22, 1996; accepted October 17, 1996).

Reprints may be obtained from: P. Maisi, Department of Clinical Veterinary Sciences, Faculty of Veterinary Medicine, University of Helsinki. P.O. Box 57, Hämeentie 57, FIN-00014, Helsinki, Finland. E-mail: paivi.maisi@helsinki.fi, tel.: 358-9-70849623, fax: 358-9-70849670. 
